\title{
Study on Freshwater Macroinvertebrates of Some Tanzanian Rivers as a Basis for Developing Biomonitoring Index for Assessing Pollution in Tropical African Regions
}

\author{
Julius D. Elias, ${ }^{1}$ Jasper N. Ijumba, $^{1}$ Yunus D. Mgaya, ${ }^{2}$ and Florence A. Mamboya ${ }^{3}$ \\ ${ }^{1}$ Department of Water and Environmental Science and Engineering (WESE), School of Materials, Energy, Water and Environmental \\ Sciences (MEWES), The Nelson Mandela African Institute of Science and Technology (NM-AIST), P.O. Box 447, Arusha, Tanzania \\ ${ }^{2}$ Department of Aquatic Sciences and Fisheries, University of Dar es Salaam, P.O. Box 35064, Dar es Salaam, Tanzania \\ ${ }^{3}$ Department of Science and Laboratory Technology, Dar es Salaam Institute of Technology, P.O. Box 2958, Dar es Salaam, Tanzania
}

Correspondence should be addressed to Julius D. Elias; animoj@yahoo.com

Received 29 June 2014; Revised 18 September 2014; Accepted 23 September 2014; Published 13 October 2014

Academic Editor: Rui Cortes

Copyright (c) 2014 Julius D. Elias et al. This is an open access article distributed under the Creative Commons Attribution License, which permits unrestricted use, distribution, and reproduction in any medium, provided the original work is properly cited.

\begin{abstract}
Macroinvertebrates and physicochemical parameters were assessed at 15 sites along five rivers in Kilimanjaro region, Tanzania, with the aim of understanding their ecological status and setting a base to the development of a biological index for tropical regions. Investigated rivers that occur within Pangani basin include Karanga, Rau, Lumbanga, Sere, and Umbwe. Sampling sites were categorized according to the level of water and habitat quality as follows: reference or least impacted (4 sites), moderately impacted ( 5 sites), and highly impacted ( 6 sites) sites. A total of 12,527 macroinvertebrates belonging to 13 orders and 48 families were recorded. The highest total abundance of 4,110 individuals per $\mathrm{m}^{2}$ was found in Karanga river, while Umbwe river had the lowest with 1,203 individuals per $\mathrm{m}^{2}$. Chironomidae was the most abundant family $\left(2,588\right.$ individuals per $\left.\mathrm{m}^{2}\right)$ and the least were Hydridae and Thiaridae, each having 5 individuals per $\mathrm{m}^{2}$. High numbers of taxa were noted among the orders: Ephemeroptera (8), Odonata (8), Diptera (7), and Trichoptera (6). In conclusion, orders with greater diversity of macroinvertebrate families offer a wide range of tolerance to pollution and, thus can potentially be used to develop a biomonitoring index for evaluating pollution in tropical African rivers.
\end{abstract}

\section{Introduction}

Freshwater macroinvertebrate species are at higher risk of extinction due to habitat degradation following overwhelming human activities (i.e., invasive industrialization, agriculture, and urban development) near rivers [1-3]. It is unlikely that there is a substantial number of freshwater bodies remaining that have not been irreversibly altered from their original state as a result of anthropogenic activities [4]. In Tanzania, for example, most of the industries are located in Dar es Salaam city and mostly discharge their waste waters into Mzinga, Msimbazi, Yombo, and Kizinga rivers, which eventually discharge into the Indian Ocean $[2,5]$. This, in turn, affects the occurrence, composition, and the distribution of freshwater macroinvertebrate species, depending on their levels of tolerance and adaptability [6-9].
In tropical African regions, researches on the status and trends of freshwater macroinvertebrates in rivers have not been given much attention compared to nontropical regions $[10,11]$. As a result, some species may already have become extinct even before they were taxonomically classified leading to lack of taxonomical information. This situation has hindered the potential use of benthic macroinvertebrates as indicators for water quality assessment and thus making biomonitoring programmes a remote possibility to these regions [10]. Alternatively, tropical biomonitoring studies are relying on indices that were developed for other regions [10]. Such adoption signals the growing interest and recent need for the use of macroinvertebrates based indices in the tropics to assess streams and river health status. Unfortunately, recorded macroinvertebrates in temperate, Mediterranean, arid, and semiarid regions did not sufficiently 
match with those in the tropics to confirm the existence of general adopting rules among macroinvertebrates based indices from other regions [11-14]. Besides, differences in climate and altitude, combined with the longitudinal position of sites, appear to be important factors governing diversity and structure of macroinvertebrate communities among regions $[11,15,16]$. Given what has been described above, taxonomical and ecological information regarding tropical African macroinvertebrates remains of major importance. This study therefore seeks to characterize macroinvertebrate communities in some Tanzanian rivers, with the aim of understanding their taxonomical and ecological status and setting a base to the development of a biomonitoring index for tropical African regions.

\section{Materials and Methods}

2.1. Description of the Study Area. Macroinvertebrate community structures and physicochemical parameters were assessed in five Tanzanian rivers located in Kilimanjaro region which flow into the Pangani basin. Investigated rivers include Karanga, Rau, Lumbanga, Sere, and Umbwe. Kilimanjaro region is located in the northern-eastern part of Tanzania mainland between $037^{\circ} 30^{\prime} 0^{\prime \prime} \mathrm{E}$ and $03^{\circ} 4^{\prime} 59^{\prime \prime} \mathrm{S}$ (Figure 1).

Karanga river flows from the foot of Mount Kilimanjaro southwards and empties into Nyumba ya Mungu dam. Three sites were identified along this river with the site near Kibo Match Industries being categorised as moderately impacted while the other two (Shirimatunda and Bonite Bottlers factory sites) are categorised as highly impacted. Major threats on this river are industrial and household wastes, agricultural activities, and habitat degradation by human activities.

Rau river flows southwards through Njoro and Kahe forests before discharging into Lake Jipe. Along the channel, one least impacted site (Mawela) and two highly impacted sites, namely, Majengo and Msaranga, were used as sampling stations. Intense land use involving cultivation of cash and food crops cultivation (with application of fertilizers and pesticides), animal grazing, and construction work have caused almost complete depletion of riparian vegetation.

Lumbanga river consists of two reference (least impacted) sites (Mweka and Singachini) and one moderately impacted site (Kirima). It drains extensively cultivated highlands, coffee estates and food croplands, settled areas, and cultivated plains before emptying into Nyumba ya Mungu dam. Along its course there are alterations of areas with no or with minor degraded reaches, whereas in some areas intact riparian vegetation is still retained.

Sere river is found on the western part of Kilimanjaro National Park. In this river, Kombo site was regarded as being least impacted, whereas Narumu and Weruweru sites were considered to be moderately impacted. The presence of coffee plantations and human settlements in the vicinity of the selected sites is the possible source of pollution that could affect the river water quality and biota.

In Umbwe river, one moderately impacted site (Umbwe upstream) and two highly impacted sites (Kwa-Rafael and Kindi) were identified and used for macrobenthic sample collection. Presence of extensive agricultural activities and human settlements in the area is the causes of watershed pollution and riparian zone degradation along the river.

2.2. Sampling Design. The five rivers were classed into three site categories, namely, reference (least impacted), moderate impacted, and highly impacted sites within which 15 sampling sites were established. The sampling sites were selected based on the (i) ease of availability, (ii) presence and absence of sustained anthropogenic activities, (iii) exhibition of high microscale heterogeneity, and (iv) level of water and habitat quality.

2.2.1. Physicochemical Data Collection. The physical parameters $(\mathrm{pH}$, dissolved oxygen, temperature, turbidity, and conductivity), as well as the four major nutrients in the water (soluble reactive phosphorous (SRP), nitrates, nitrites, and ammonia), were measured. Measurements of stream water temperature, conductivity, dissolved oxygen (DO), and $\mathrm{pH}$ were recorded in situ at each established site using a multisensor probe YSI Professional Plus Water Quality Instrument (Model 6050000). Turbidity was measured using turbidity meter by Hatch Instrument Limited. Determination of nutrients involved collection of water samples from running water at each site, filtering it using $0.45 \mu \mathrm{m}$ glass fiber filters before being placed in hydrochloric acid washed polythene bottles. The samples were also preserved in a cool box at about $\leq 10^{\circ} \mathrm{C}$ before being transported to the Department of Aquatic Sciences and Fisheries Laboratory at the University of Dar es Salaam for analysis.

In the laboratory, nitrate $\left(\mathrm{NO}_{3}{ }^{-}-\mathrm{N}\right)$, nitrite $\left(\mathrm{NO}_{2}{ }^{-}-\mathrm{N}\right)$, ammonia $\left(\mathrm{NH}_{4}{ }^{+}-\mathrm{N}\right)$, and $\mathrm{SRP}\left(\mathrm{PO}_{4}{ }^{3-}-\mathrm{P}\right)$ were analyzed using standard spectrophotometric methods described in APHA [17]. Nitrate and nitrite were determined using the cadmium reduction method followed by diazotization with sulphanilamide and coupling with $\mathrm{N}$-(1-naphthyl)ethylenediamine to form a highly coloured azo dye that is measured spectrophotometrically at $545 \mathrm{~nm}$ wavelength. Ammonia was determined using a phenate method which forms a blue indophenol colour measured at wavelength of $640 \mathrm{~nm}$ whereby SRP was analyzed using the molybdate ascorbic acid method which results in a formation of intense blue colour measured at wavelength of $880 \mathrm{~nm}$.

\subsubsection{Macroinvertebrates Sampling. Macroinvertebrates} sampling was conducted in accordance with methods for assessing biological integrity of surface waters [18]. Three benthic samples were obtained from each site using Hess sampler. The Hess sampler was placed into the water while being positioned against water flow direction. Stream substrate was disturbed ten times for 30 seconds in order to collect macroinvertebrate samples. Macroinvertebrate samples representative of the range of water flow conditions collected from all possible microhabitats were pooled into single sample for each site. To eliminate effects of substrate diversity biasing the semiquantitative sampling, an effort was made to sample riffle habitats that afforded 


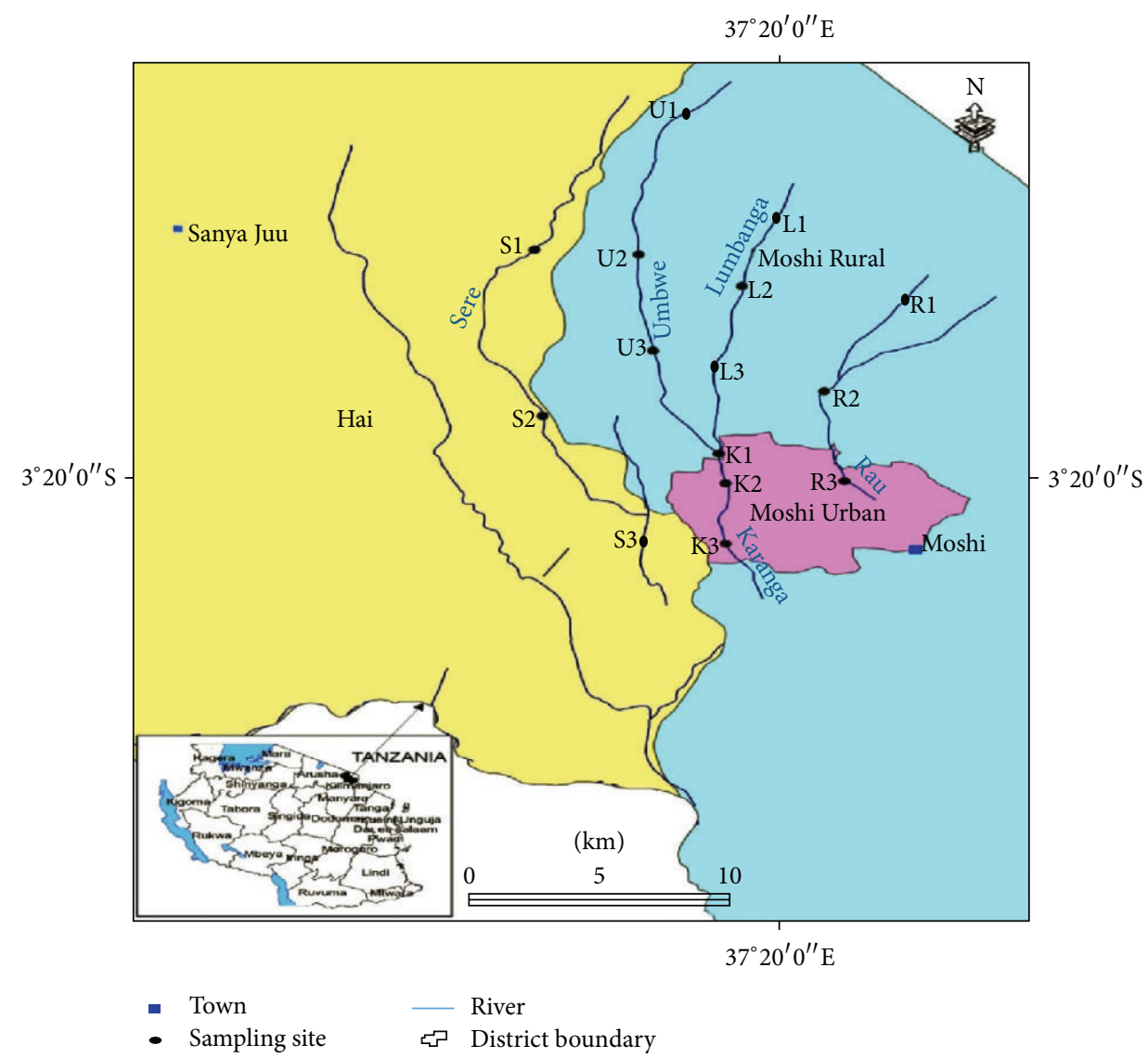

FIGURE 1: Map showing sampling sites along Karanga, Rau, Lumbanga, Sere, and Umbwe rivers. Key: K1 = Karanga site @Kibo Match Industry Ltd.; K2 = Karanga site @Shirimatunda; K3 = Karanga site @Bonite Bottlers Factory Ltd.; R1 = Rau site @Mawela; R2 = Rau site @Majengo; R3 = Rau site @Msaranga; L1 = Lumbanga site@Mweka; L2 = Lumbanga site @Singachini; L3=Lumbanga site @Kirima; S1=Sere site@Kombo; S2=Sere site @Narumu; S3 = Sere site @Weruweru; U1 = Umbwe upstream site; U2 = Umbwe site @Kwa-Rafael; U3 = Umbwe site @Kindi.

macroinvertebrates with the best arrangement or layering of cobble, gravel, and small boulders. Nonriffle habitats were sampled qualitatively to try to collect as many specimens as possible within the stream reach.

The collected benthic samples were stored in well-labelled bottles and preserved in 10\% formaldehyde (formalin) before being transported to the Department of Aquatic Sciences and Fisheries Laboratory at the University of Dar es Salaam. Prior to identification, each sample was rinsed thoroughly to remove all traces of formalin. In the laboratory, 500 and $100 \mu \mathrm{m}$ sieves were used for sample fractioning and removal of excess sediment. For sites with high abundance of individuals like Kibo match and Shirimatunda in Karanga river and Majengo in Rau river, the subsampling technique was used to isolate at least 200 individuals from the original composite sample. Fauna remaining in the composite sample was assessed and single individuals representing rare ones not already included in the $200+$ individual subsamples were added to original composite sample. All specimens collected were sorted, enumerated, and identified to family level with the help of available keys, that is, Aquatic Invertebrates of South African Rivers [19] under a stereomicroscope at $10 \times 45$ magnification followed by listing and counting of individuals.
2.2.3. B-IBI Scores. B-IBI (Benthic Index of Biological Integrity) was calculated at each site according to Barbour et al. [18] using percentage composition of 14 metrics (including H-FBI), excluding abundance. These include \%Baetidae, \%Dominant taxa, \%Taxa richness, \%Ephemeroptera, \%Plecoptera, \%Trichoptera, \%Odonata, \%EPT, \%H-FBI, \%Noninsect taxa, \%Diptera, \%Chironomidae and \%Oligochaeta, and Shannon Diversity Index. The range of numbers observed for each of these characteristics was divided into 3 categories that represent values expected from least stressed (reference sites), intermediate (moderately impacted sites), and most stressed communities (highly impacted sites). Depending on the range into which a specific characteristic at a particular site falls, a score of 5,3 , or 1 (referred to as "standardized scores") was assigned. The score of 5 stands for reference sites, 3 for moderately impacted sites, and 1 for highly impacted sites. Since B-IBI value is the sum of these character scores and generates a maximal (least stressed) score of 70 (14 characters each with a maximal score of 5) and a minimal value (most stressed) of $14 \times 1=14$, B-IBI values were calculated in this way for each site. The B-IBI values were then standardized to 100 -point scale giving 100 (least stressed), 60 (moderate), and 20 (most stressed) B-IBI 
TABLE 1: Methods of classification of water quality status based on impairment level from B-IBI data.

\begin{tabular}{lcc}
\hline B-IBI value & $\begin{array}{c}\text { Water quality } \\
\text { characterization }\end{array}$ & Impairment \\
\hline $20-46$ & Very poor to poor & Severe \\
$>46-72$ & Fair to good & $\begin{array}{c}\text { Moderate } \\
\text { Very little to } \\
\text { none }\end{array}$ \\
\hline
\end{tabular}

values. To categorize the sites into various impairment levels, the range of B-IBI numbers was divided into 3 subranges, and then impairment levels were given as shown in Table 1. Therefore, the 100-point scale B-IBI values calculated at the family level may correspond to the following water quality assessments (Table 1).

2.3. Statistical Analysis. Statistical software InStat version 3 (GraphPad), PASW Statistics 18, and Excel spreadsheet were used for analysis. Physicochemical parameters were expressed as means \pm standard error $(\mathrm{M} \pm \mathrm{SE})$; macroinvertebrate count data were $\log _{10}(x+1)$ transformed to meet the statistical criteria for normality. One-way analysis of variance (ANOVA, $\alpha=0.05$ ) and Pearson rank correlation were used to test whether the physicochemical parameters and benthic macroinvertebrates differed among the rivers and site categories $[20,21]$. The macroinvetebrates data were subjected to Bray-Curtis similarity analysis to reveal resemblance among sites and rivers.

\section{Results}

3.1. Environmental Variables. The environmental variables that have been used in this study to understand the criteria defining the 3 site categories (classes) are physical and chemical (nutrients) parameters. They are the baseline against which the effectiveness of benthic macroinvertebrates to reflect the water quality is measured $[3,22,23]$. With exception of DO, there was a distinct trend of environmental variables at the highly impacted sites being higher than at other site categories (Figures 2 and 3). One-way ANOVA revealed higher significant differences in turbidity $\left(F_{(2,12)}=\right.$ 25.962; $P<0.0001)$, $\mathrm{DO}\left(F_{(2,12)}=14.022 ; P=0.0007\right)$, and nitrate $\left(F_{(2,12)}=7.255 ; P=0.0086\right)$ between reference sites and highly impacted sites as well as at reference versus moderately impaired sites. However, $\mathrm{pH}\left(F_{(2,12)}=2.336\right.$; $P=0.1391)$, temperature $\left(F_{(2,12)}=1.207 ; P=0.3329\right)$, nitrite $\left(F_{(2,12)}=0.6839 ; P=0.5233\right), \operatorname{SRP}\left(F_{(2,12)}=5.373\right.$; $P=0.0216)$, conductivity $\left(F_{(2,12)}=5.781 ; P=0.0175\right)$, and ammonia $\left(F_{(2,12)}=5.372 ; P=0.0216\right)$ values showed no or very slight variations among the three site categories with $\mathrm{pH}$ values being mostly close to neutral.

3.2. Macroinvertebrates. A total of 12,527 macroinvertebrates belonging to 13 orders and 48 families from 15 sites of the 5 sampled rivers were collected, sorted, and counted (Table 2). Among all identified families, 33 were common

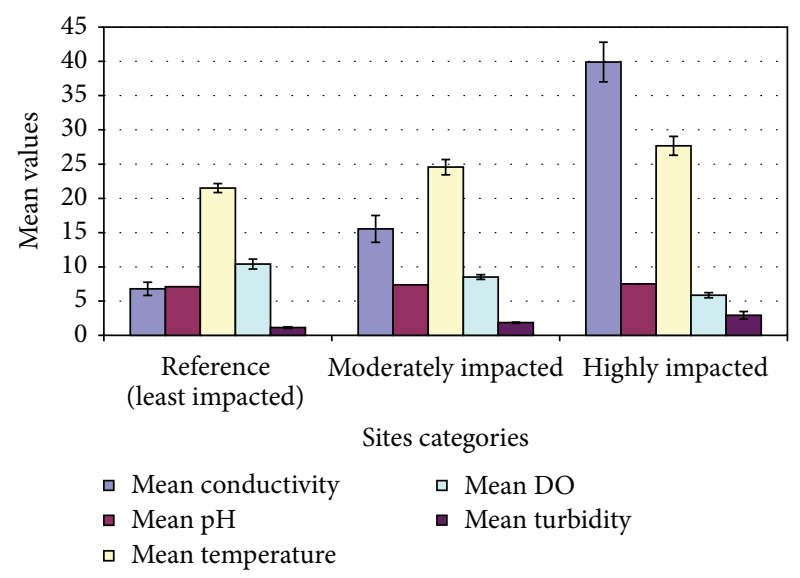

FIGURE 2: Mean physical parameter values recorded at three site categories.

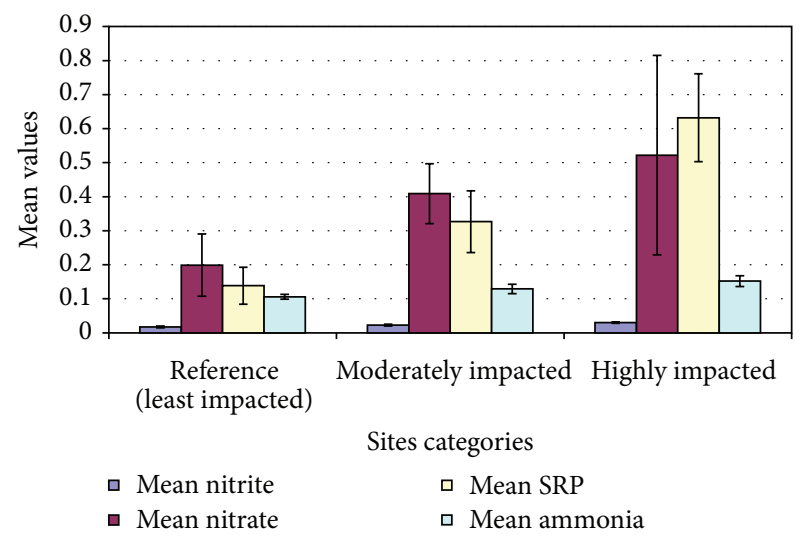

Figure 3: Mean chemical parameter values recorded at three site categories.

and 15 were rare. Most of the rare families were identified from reference sites. Ephemeroptera and Odonata were the most diverse taxa, consisting of 8 families each, followed by Diptera and Trichoptera with 7 and 6 families, respectively. Arhynchobdellida, Decapoda, Hydroida, Plecoptera, Tubificida, and Tricladida were orders found with the least diverse taxa consisting of one family each.

The highest total abundance of 4,110 individuals per $\mathrm{m}^{2}$ was counted at Karanga river while the lowest (1,203 individuals per $\mathrm{m}^{2}$ ) was recorded within Umbwe river. Again the highest total abundances of 2,057 and 608 individuals per $\mathrm{m}^{2}$ were recorded at downstream sites of Karanga and Umbwe rivers, respectively. Chironomidae was the most abundant family collected with 2,588 individuals, followed by Simuliidae (1955 individuals) and Baetidae (1,898 individuals) families. Hydridae and Thiaridae were the least abundant families, found with only 5 individuals each and followed by Planorbidae with 8 individuals.

B-IBI scores calculated from 14 biometric data have demonstrated a decreasing pattern from least (reference) to highly impacted sites (Figure 4). Lumbanga river had good water quality with significantly higher B-IBI value of $57 \%$ 
TABLE 2: Macroinvertebrate families recorded at each site of the five studied rivers.

\begin{tabular}{|c|c|c|c|c|c|c|c|c|c|c|c|c|c|c|c|c|c|}
\hline Order & Family & $\mathrm{K} 1$ & $\mathrm{~K} 2$ & K3 & R1 & R2 & R3 & L1 & $\mathrm{L} 2$ & L3 & S1 & S2 & S3 & U1 & $\mathrm{U} 2$ & U3 & Total \\
\hline Arhynchobdellida & Hirudinidae & 1 & 0 & 0 & 4 & 0 & 0 & 1 & 1 & 8 & 3 & 2 & 0 & 0 & 0 & 0 & 20 \\
\hline \multirow{5}{*}{ Coleoptera } & Dytiscidae & 0 & 15 & 7 & 3 & 17 & 13 & 14 & 0 & 21 & 7 & 5 & 12 & 6 & 1 & 3 & 124 \\
\hline & Dryopidae & 0 & 0 & 2 & 19 & 7 & 11 & 38 & 29 & 17 & 3 & 10 & 7 & 16 & 17 & 87 & 263 \\
\hline & Gyrinidae & 0 & 16 & 4 & 16 & 18 & 3 & 10 & 0 & 32 & 0 & 3 & 2 & 13 & 8 & 13 & 138 \\
\hline & Haliplidae & 3 & 0 & 0 & 9 & 0 & 0 & 4 & 4 & 5 & 10 & 3 & 0 & 0 & 0 & 0 & 38 \\
\hline & Hydrophilidae & 2 & 2 & 3 & 2 & 11 & 1 & 2 & 2 & 14 & 0 & 2 & 3 & 9 & 2 & 9 & 64 \\
\hline Decapoda & Potamonautidae & 18 & 27 & 41 & 8 & 2 & 20 & 1 & 6 & 3 & 2 & 2 & 11 & 4 & 17 & 6 & 168 \\
\hline \multirow{7}{*}{ Diptera } & Athericidae & 34 & 73 & 123 & 21 & 64 & 81 & 3 & 4 & 11 & 11 & 34 & 26 & 1 & 43 & 19 & 548 \\
\hline & Ceratopogonidae & 58 & 22 & 56 & 5 & 25 & 14 & 4 & 5 & 14 & 4 & 10 & 27 & 11 & 17 & 10 & 282 \\
\hline & Chironomidae & 294 & 456 & 607 & 63 & 368 & 369 & 1 & 6 & 45 & 29 & 56 & 49 & 13 & 37 & 195 & 2588 \\
\hline & Muscidae & 21 & 47 & 56 & 15 & 28 & 32 & 2 & 27 & 14 & 16 & 18 & 34 & 24 & 12 & 6 & 352 \\
\hline & Simuliidae & 54 & 275 & 647 & 67 & 261 & 296 & 10 & 68 & 17 & 35 & 31 & 29 & 14 & 28 & 123 & 1955 \\
\hline & Tabanidae & 42 & 53 & 106 & 20 & 37 & 64 & 3 & 15 & 6 & 16 & 32 & 38 & 20 & 16 & 11 & 479 \\
\hline & Tipulidae & 45 & 30 & 85 & 4 & 18 & 24 & 16 & 15 & 13 & 29 & 27 & 66 & 27 & 34 & 16 & 449 \\
\hline \multirow{8}{*}{ Ephemeroptera } & Baetidae & 31 & 16 & 9 & 284 & 7 & 18 & 480 & 337 & 31 & 353 & 279 & 37 & 13 & 1 & 2 & 1898 \\
\hline & Caenidae & 7 & 4 & 1 & 94 & 9 & 7 & 104 & 94 & 11 & 42 & 27 & 16 & 11 & 1 & 0 & 428 \\
\hline & Dicercormyzidae & 14 & 0 & 0 & 9 & 0 & 0 & 54 & 28 & 11 & 9 & 16 & 0 & 0 & 0 & 0 & 141 \\
\hline & Ephemerythidae & 2 & 0 & 0 & 16 & 0 & 0 & 2 & 4 & 7 & 4 & 2 & 0 & 0 & 0 & 0 & 37 \\
\hline & Heptageniidae & 6 & 0 & 0 & 3 & 0 & 0 & 5 & 2 & 5 & 6 & 2 & 0 & 0 & 0 & 0 & 29 \\
\hline & Leptophlebiidae & 8 & 0 & 0 & 2 & 0 & 0 & 11 & 6 & 2 & 3 & 7 & 0 & 0 & 0 & 0 & 39 \\
\hline & Oligoneuriidae & 7 & 0 & 0 & 10 & 0 & 0 & 16 & 8 & 2 & 5 & 1 & 0 & 0 & 0 & 0 & 49 \\
\hline & Polymitarcyidae & 2 & 0 & 0 & 4 & 0 & 0 & 12 & 8 & 2 & 1 & 3 & 1 & 3 & 0 & 0 & 36 \\
\hline \multirow{3}{*}{ Gastropoda } & Lymnaeidae & 0 & 3 & 0 & 1 & 0 & 1 & 3 & 0 & 1 & 0 & 0 & 0 & 1 & 0 & 0 & 10 \\
\hline & Planorbidae & 1 & 0 & 2 & 0 & 0 & 0 & 1 & 1 & 0 & 1 & 0 & 0 & 2 & 0 & 0 & 8 \\
\hline & Thiaridae & 1 & 0 & 0 & 1 & 0 & 0 & 1 & 1 & 0 & 0 & 0 & 0 & 1 & 0 & 0 & 5 \\
\hline \multirow{5}{*}{ Hemiptera } & Corixidae & 5 & 18 & 11 & 7 & 23 & 22 & 17 & 7 & 45 & 6 & 54 & 31 & 23 & 17 & 9 & 295 \\
\hline & Gerridae & 1 & 0 & 3 & 0 & 4 & 12 & 2 & 6 & 18 & 2 & 13 & 7 & 10 & 3 & 7 & 88 \\
\hline & Naucoridae & 1 & 6 & 0 & 23 & 0 & 0 & 28 & 0 & 37 & 2 & 0 & 0 & 35 & 1 & 10 & 143 \\
\hline & Notonectidae & 3 & 21 & 3 & 0 & 14 & 8 & 13 & 8 & 51 & 23 & 41 & 20 & 10 & 6 & 4 & 225 \\
\hline & Veliidae & 1 & 3 & 10 & 4 & 1 & 4 & 7 & 2 & 14 & 5 & 2 & 9 & 5 & 2 & 0 & 69 \\
\hline Hydroida & Hydridae & 0 & 0 & 0 & 1 & 0 & 0 & 1 & 1 & 1 & 1 & 0 & 0 & 0 & 0 & 0 & 5 \\
\hline \multirow{8}{*}{ Odonata } & Aeshnidae & 0 & 6 & 1 & 6 & 2 & 4 & 1 & 6 & 4 & 1 & 4 & 1 & 0 & 1 & 4 & 41 \\
\hline & Calopterygidae & 1 & 1 & 1 & 1 & 3 & 0 & 0 & 0 & 2 & 1 & 1 & 1 & 1 & 1 & 0 & 14 \\
\hline & Chlorocyphidae & 1 & 0 & 0 & 3 & 1 & 1 & 0 & 0 & 1 & 1 & 0 & 0 & 0 & 1 & 1 & 10 \\
\hline & Coenagrionidae & 2 & 24 & 3 & 4 & 1 & 3 & 0 & 8 & 3 & 6 & 4 & 1 & 2 & 1 & 3 & 65 \\
\hline & Corduliidae & 2 & 1 & 0 & 1 & 3 & 4 & 1 & 1 & 6 & 2 & 2 & 2 & 5 & 9 & 13 & 52 \\
\hline & Gomphidae & 0 & 4 & 2 & 2 & 3 & 1 & 0 & 6 & 5 & 0 & 5 & 3 & 0 & 1 & 1 & 33 \\
\hline & Libellulidae & 0 & 2 & 17 & 5 & 5 & 7 & 0 & 5 & 8 & 4 & 7 & 1 & 1 & 1 & 0 & 63 \\
\hline & Macromiidae & 0 & 15 & 14 & 2 & 0 & 2 & 0 & 9 & 15 & 0 & 3 & 3 & 0 & 6 & 8 & 77 \\
\hline Plecoptera & Perlidae & 8 & 0 & 0 & 11 & 0 & 0 & 4 & 6 & 15 & 0 & 12 & 21 & 1 & 0 & 0 & 78 \\
\hline Tubificida & Naididae & 67 & 117 & 211 & 68 & 92 & 129 & 0 & 1 & 2 & 0 & 15 & 19 & 3 & 18 & 46 & 788 \\
\hline Tricladida (Turbellaria) & Planariidae & 1 & 0 & 0 & 0 & 0 & 0 & 19 & 2 & 1 & 1 & 2 & 0 & 1 & 0 & 0 & 27 \\
\hline \multirow{6}{*}{ Trichoptera } & Ecnomidae & 0 & 1 & 0 & 5 & 1 & 0 & 14 & 13 & 1 & 19 & 12 & 1 & 1 & 1 & 0 & 69 \\
\hline & Hydropsychidae & 0 & 0 & 1 & 11 & 1 & 0 & 7 & 7 & 1 & 13 & 4 & 0 & 3 & 0 & 0 & 48 \\
\hline & Lepidostomatidae & 1 & 0 & 0 & 9 & 0 & 1 & 5 & 4 & 0 & 4 & 5 & 0 & 1 & 2 & 1 & 33 \\
\hline & Leptoceridae & 2 & 0 & 0 & 1 & 0 & 0 & 13 & 6 & 1 & 14 & 9 & 1 & 0 & 0 & 0 & 47 \\
\hline & Philopotamidae & 1 & 0 & 0 & 3 & 0 & 0 & 23 & 16 & 0 & 10 & 21 & 0 & 0 & 0 & 0 & 74 \\
\hline & Phryganeidae & 3 & 0 & 0 & 8 & 0 & 0 & 7 & 4 & 2 & 5 & 2 & 3 & 1 & 0 & 0 & 35 \\
\hline Total & & 751 & 1258 & 2026 & 855 & 1026 & 1152 & 960 & 789 & 525 & 709 & 790 & 482 & 292 & 305 & 607 & 12527 \\
\hline
\end{tabular}

Key: K1= Karanga site @ Kibo Match Industry Ltd.; K2 = Karanga site @ Shirimatunda; K3 = Karanga site @ Bonite Bottlers Factory Ltd.; R1= Rau site @ Mawela; R2=Rau site@ Majengo; R3=Rau site@ Msaranga; L1=Lumbanga site @ Mweka; L2=Lumbanga site @ Singachini; L3=Lumbanga site @ Kirima; S1=Sere site@ Kombo; S2 = Sere site @ Narumu; S3= Sere site @ Weruweru; U1=Umbwe upstream site; U2= Umbwe site @ Kwa-Rafael; U3= Umbwe site @ Kindi. 
TABLE 3: Categorization of sites into different impairment levels based on B-IBI results.

\begin{tabular}{lccc}
\hline B-IBI value & Water quality characterization & Impairment & Sites fall at each impairment level \\
\hline $20-46$ & Very poor to poor & Severe & U3, K1, R2, K2, R3, and K3 \\
$>46-72$ & Fair to good & Moderate & U1, U2, and S3 \\
$>72-100$ & Very good to excellent & Very little to none & L1, L2, L3, R1, S1, and S2 \\
\hline
\end{tabular}

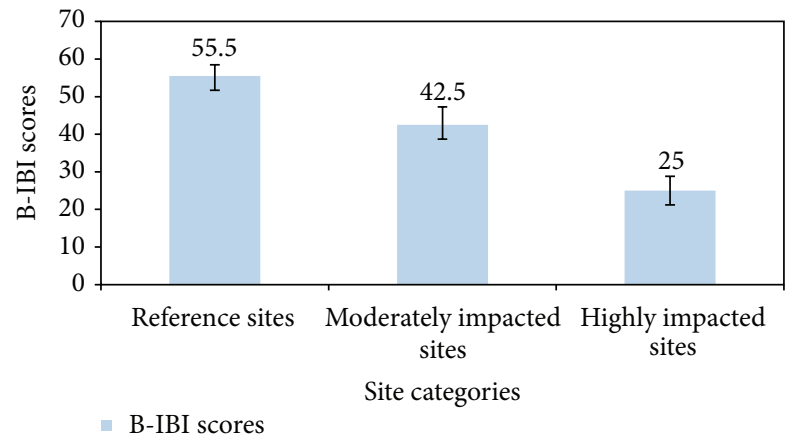

FIGURE 4: B-IBI scores of the site categories showing a decreasing pattern from reference to highly impacted sites.

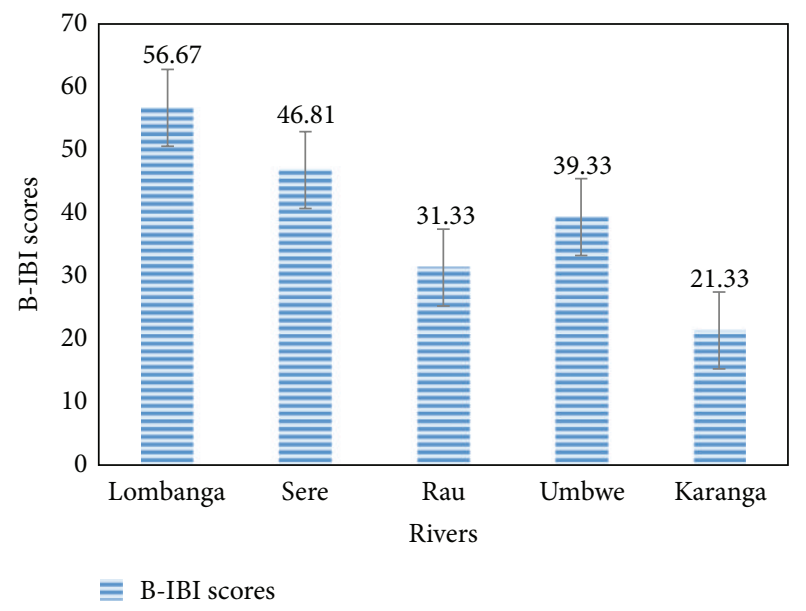

FIGURE 5: B-IBI scores of studied rivers showing their impairment levels.

compared to Karanga that falls within a very poor water quality with B-IBI score of $21 \%$ (Figure 5). Moreover, statistical findings in Table 3 suggest that some reference sites were similar to moderately impacted sites and vice versa. A similar overlapping character was also found between moderately and highly impacted sites. Table 3 has also categorized the sites with less and/or very little impairment (L1, L2, L3, R1, S1, and S2) as reference (least impacted) sites; sites with moderate impairment (U1, U2, and S3) as moderately impacted sites; and those with major disturbance (K1, K2, K3, R2, R3, and U3) as highly impacted sites.

Cluster analysis done using Bray-Curtis similarity dendrogram revealed some similarities between macroinvertebrates among sites and among rivers (Figures 6 and 7). R2 and R3 showed a very close similarity of macroinvertebrates
Bray-Curtis cluster analysis (single link)

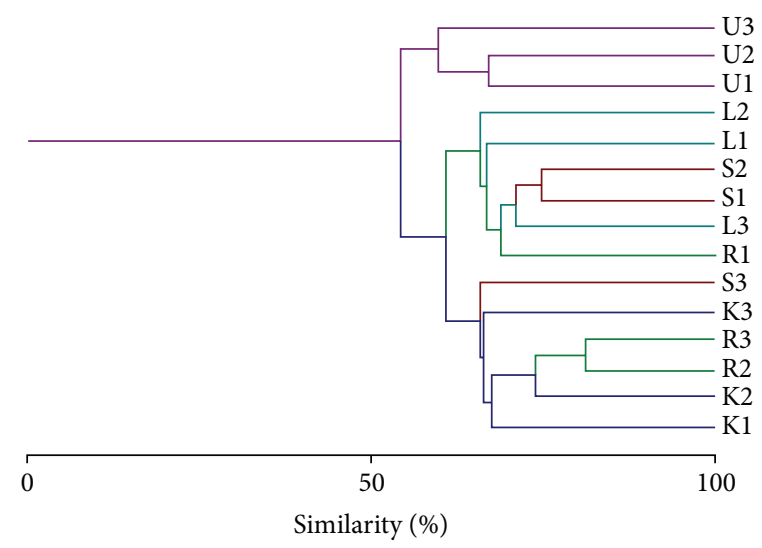

FIGURE 6: Bray-Curtis similarity dendrogram showing similarities of sampling sites in abundance of macroinvertebrates.

Bray-Curtis cluster analysis (single link)
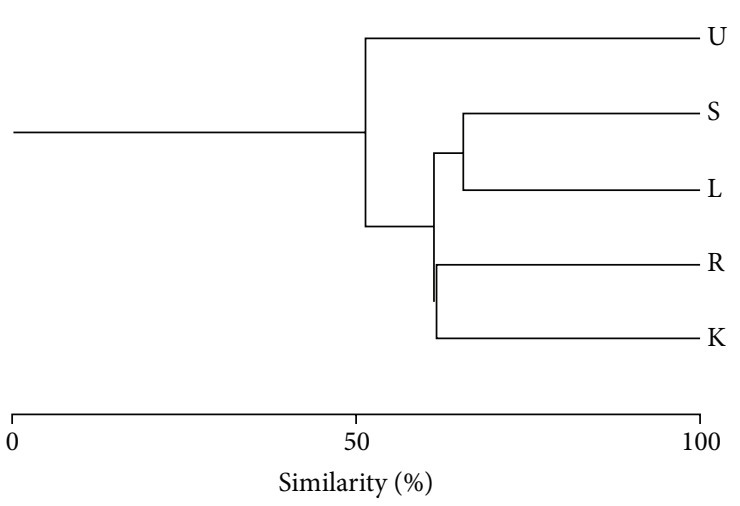

FIGURE 7: Bray-Curtis similarity dendrogram showing similarities of sampled rivers in abundance of macroinvertebrates.

abundance as compared to other sites of about $80 \%$. S1 and S2 showed a close similarity in terms of abundance of macroinvertebrates of about $75 \%$. Generally, all sites showed a close similarity with regard to abundance of macroinvertebrates of more than 55\% excluding sampling site U3 (Figure 6).

Sere and Lumbanga rivers showed a close similarity of number of macroinvertebrates of about $65 \%$. Rau and Karanga rivers showed a similarity of abundance of macroinvertebrates of about $55 \%$. Umbwe river had a similarity of abundance of macroinvertebrates with the rest of other rivers at less than 55\% (Figure 7). 


\section{Discussion}

Presence or absence of macroinvertebrates in any given freshwater ecosystem is a function of habitat quality, physicochemical parameters, and the regional taxonomic pool [3, $9,23,24]$. Consequently, a wide variety of freshwater habitat and water chemistry offers the potential for a high diversity of freshwater macroinvertebrates [3, 23-26]. Macroinvertebrate communities at degraded sites are characterized by either absence of any sensitive taxa or presence of few if any; greater dominance of only few taxa; and larger numbers of macroinvertebrates that are tolerant to pollution [21]. Indeed, a strong relationship observed in this study between the families found and the degradation of the watercourses appears to support such contention. Families of orders Ephemeroptera (Dicercormyzidae, Ephemerythidae, Heptageniidae, Oligoneuriidae, and Polymitarcyidae) and Trichoptera (Lepidostomatidae, Leptoceridae, Philopotamidae, and Phryganeidae), for example, disappeared or their numbers reduced drastically in impacted sites as opposed to some Diptera and Odonata taxa which were observed in all sites. The complete absence of these taxa from impacted sites is probably related to the differences of instream environmental degradation along rivers as a result of human activities, that is, agriculture, urbanization, and industrialization. However, total disappearances of these taxa from all disturbed sites and the continuous presence of the Ephemeroptera (8 taxa), Odonata (8 taxa), Diptera (7 taxa), and Trichoptera (6 taxa) in all sampled sites suggest their potential use as key indicators of water quality assessment for biomonitoring programmes.

The study also showed that increased total abundance does not necessarily depict better environment but rather might be due to mild disturbance that favors some tolerant taxa with subsequent reduction of sensitive taxa. Presence of least sensitive taxa to pollution (i.e., Chironomids) in all site categories further suggests the notion that they are good colonizers and appear under a range of conditions [3]. Since highly impacted sites cannot provide habitat suitable for very sensitive macroinvertebrates, the Chironomids which are able to withstand high levels of organic pollution due to their high haemoglobin affinity $[3,13,27]$ can thrive there. Moreover, the abundance of Chironomids also correlates with the amount of detritus or fine particulate organic matter in the sediment as they are considered tolerable [28]. As reported by Eggermont and Verschuren [29], the Dipteran family Chironomidae and midge larvae may also be more effective indicators of increased stress, due to their abundance domination in impacted sites compared to other families. However, general response among macroinvertebrate families toward pollution levels requires the identification to be done to a possible lower level for more precision before being used to develop an index for tropical African regions.

B-IBI scores have shown the wide range in water quality along the rivers, with upstream sites having good water quality compared to middle and downstream sites. The decreased trend of DO and elevated trend of other recorded physicochemical parameters towards rivers mouth might be associated with watershed disturbances as well as rural and urban organic loading [24]. Streams in which highly impacted sites were found to have the worst metric scores had lost much of their capacity to support diversity of pollution sensitive taxa. This however has led to adverse change in faunal structure within the rivers and thus calls for biomonitoring programmes aiming at ecosystem restoration.

\section{Conclusion}

Generally, this study has provided the first comprehensive set of published ecological and taxonomical data describing macroinvertebrate communities at reference and moderately and highly impacted sites in Tanzania. Macroinvertebrate organisms were shown to be potentially good quality indicators in tropical African regions and the remarkably high number of taxa collected could be an interesting source of information. However, there is a need for more intensive study on the entire length of other Tanzanian river basins to fully comprehend the general freshwater organisms of the rivers involved. As macroinvertebrates remained to be a key indicator of pollution in aquatic ecosystems, orders with more diverse taxa (i.e., Ephemeroptera, Odonata, Diptera, and Trichoptera) that offer a wide range of pollution tolerance or sensitivity have the potential to be part of tropical African biomonitoring programmes.

\section{Conflict of Interests}

The authors declare that there is no conflict of interests regarding the publication of this paper.

\section{Acknowledgments}

The authors wish to thank Dr. Kithongo Kingondu for helpful comments and/or suggestions and Tanzania Commission for Science and Technology (COSTECH) together with International Foundation for Science (IFS) for financial support.

\section{References}

[1] K. Jamil, Bioindicators and Biomarkers of Environmental Pollution and Risk Assessment, Science Publishers, Enfield, NH, USA, 2001.

[2] C. Lévêque and E. V. Balian, "Conservation of freshwater biodiversity: does the real world meet scientific dreams?" Hydrobiologia, vol. 542, no. 1, pp. 23-26, 2005.

[3] G. E. Likens, Lake Ecosystem Ecology, Academic Press, San Diego, Calif, USA, 2010.

[4] O. E. Sala, F. S. Chapin III, J. J. Armesto et al., "Global biodiversity scenarios for the year 2100," Science, vol. 287, no. 5459, pp. 1770-1774, 2000.

[5] J. Ak'habuhaya and M. Lodenius, "Metal pollution of River Msimbazi, Tanzania," Environment International, vol. 14, no. 6, pp. 511-514, 1989.

[6] R. K. Hall, G. A. Wolinsky, P. Husby et al., "Status of aquatic bioassessment in U.S. EPA Region IX," Environmental Monitoring and Assessment, vol. 64, no. 1, pp. 17-30, 2000.

[7] J. R. Karr and E. W. Chu, "Sustaining living rivers," Hydrobiologia, vol. 422-423, pp. 1-14, 2000. 
[8] J. Böhmer, C. Rawer-Jost, and A. Zenker, "Multimetric assessment of data provided by water managers from Germany: assessment of several different types of stressors with macrozoobenthos communities," Hydrobiologia, vol. 516, no. 1-3, pp. 215-228, 2004.

[9] K. Suleiman and I. L. Abdullahi, "Biological assessment of water quality: a study of Challawa river water in Kano, Nigeria," Bayero Journal of Pure and Applied Sciences, vol. 4, no. 2, pp. 121-127, 2011.

[10] J. D. Elias, J. N. Ijumba, and F. A. Mamboya, "Effectiveness and compatibility of non-tropical biomonitoring indices for assessing pollution in tropical rivers-a review," International Journal of Ecosystem, vol. 4, no. 3, pp. 128-134, 2014.

[11] D. M. Umar, J. S. Harding, and M. J. Winterbourn, Freshwater Invertebrates of the Mambilla Plateau, Nigeria, Gombe State University and University of Canterbury, 2013.

[12] T. J. Blakely, J. S. Harding, E. Clews, and M. J. Winterbourn, An Illustrated $G$ uide to the Freshwater Macroinvertebrates of Singapore, School of Biological Sciences, University of Canterbury, Christchurch, UK, 2010.

[13] F. O. Masese, P. O. Raburu, and M. Muchiri, "A preliminary benthic macroinvertebrate index of biotic integrity (B-IBI) for monitoring the Moiben River, Lake Victoria Basin, Kenya," African Journal of Aquatic Science, vol. 34, no. 1, pp. 1-14, 2009.

[14] G. W. Ngupula and R. Kayanda, "Benthic macrofauna community composition, abundance and distribution in the Tanzanian and Ugandan inshore and offshore waters of Lake Victoria," African Journal of Aquatic Science, vol. 35, no. 2, pp. 185-192, 2010.

[15] A. J. Boulton, L. Boyero, A. P. Covich, M. Dobson, S. Lake, and R. Pearson, "Are tropical streams ecologically different from temperate streams?" in Tropical Stream Ecology, D. Dudgeon, Ed., pp. 257-284, Elsevier, London, UK, 2008.

[16] R. G. Pearson and L. Boyero, "Gradients in regional diversity of freshwater taxa," Journal of the North American Benthological Society, vol. 28, no. 2, pp. 504-514, 2009.

[17] APHA, Standard Methods for the Examination of Water and Wastewater, American Public Health Association, Washington, D.C., USA, 20th edition, 1998.

[18] M. T. Barbour, J. Gerritsen, B. D. Snyder, and J. B. Stribling, Rapid Bioassessment Protocols for Use in Streams and Wadeable Rivers: Periphyton, Benthic Macroinvertebrates and Fish, EPA 841-B-99-002, U.S. Environmental Protection Agency; Office of Water, Washington, DC, USA, 2nd edition, 1999.

[19] A. Gerber and M. J. M. Gabriel, Aquatic Invertebrates of South African Rivers. Field Guide, Institute for Water Quality Studies, Vol. I and II., 2002.

[20] B. L. Hayford and J. Ferrington, "Biological assessment of Cannon Creek, Missouri by use of emerging chironomidae (Insecta: Diptera)," Journal of the Kansas Entomological Society, vol. 78, no. 2, pp. 89-99, 2005.

[21] E. Lyimo, Amphibian and Benthic Macroinvertebrate Response to Physical and Chemical Properties of Themi River, Arusha, Tanzania, Faculty of Applied Ecology and Agricultural Sciences, Hedmark University College, Elverum, Norway, 2012.

[22] M. S. Bird, Effects of habitat transformation on temporary wetlands in the South-Western Cape, South Africa [Ph.D. thesis], Faculty of Science, University of Cape Town, Cape Town, South Africa, 2012.

[23] R. W. Merritt, K. W. Cummins, and M. B. Berg, An Introduction to the Aquatic Insects of North America, Kendall/Hunt Publishing Company, Dubuque, Iowa, USA, 4th edition, 2008.
[24] M. Akasaka, N. Takamura, H. Mitsuhashi, and Y. Kadono, "Effects of land use on aquatic macrophyte diversity and water quality of ponds," Freshwater Biology, vol. 55, no. 4, pp. 909-922, 2010.

[25] C. E. Cushing and J. D. Allan, Streams: Their Ecology and Life, Abiotic Factors, Academic Press, San Diego, Calif, USA, 2001.

[26] K. K. Sharma and S. Chowdhury, "Macroinvertebrate assemblages as biological indicators of pollution in a Central Himalaya River, Tawi," International Journal of Biodiversity and Conservation, vol. 3, no. 5, pp. 167-174, 2011.

[27] J. H. Thorn and A. P. Covich, Ecology and Classification of North American Freshwater Invertebrates, Academic Press, San Diego, Calif, USA, 1991.

[28] T. P. Boyle and H. D. Fraleigh Jr., "Natural and anthropogenic factors affecting the structure of the benthic macroinvertebrate community in an effluent-dominated reach of the Santa Cruz River, AZ," Ecological Indicators, vol. 3, no. 2, pp. 93-117, 2003.

[29] H. Eggermont and D. Verschuren, "Impact of soil erosion in disturbed tributary drainages on the benthic invertebrate fauna of Lake Tanganyika, East Africa," Biological Conservation, vol. 113, no. 1, pp. 99-109, 2003. 

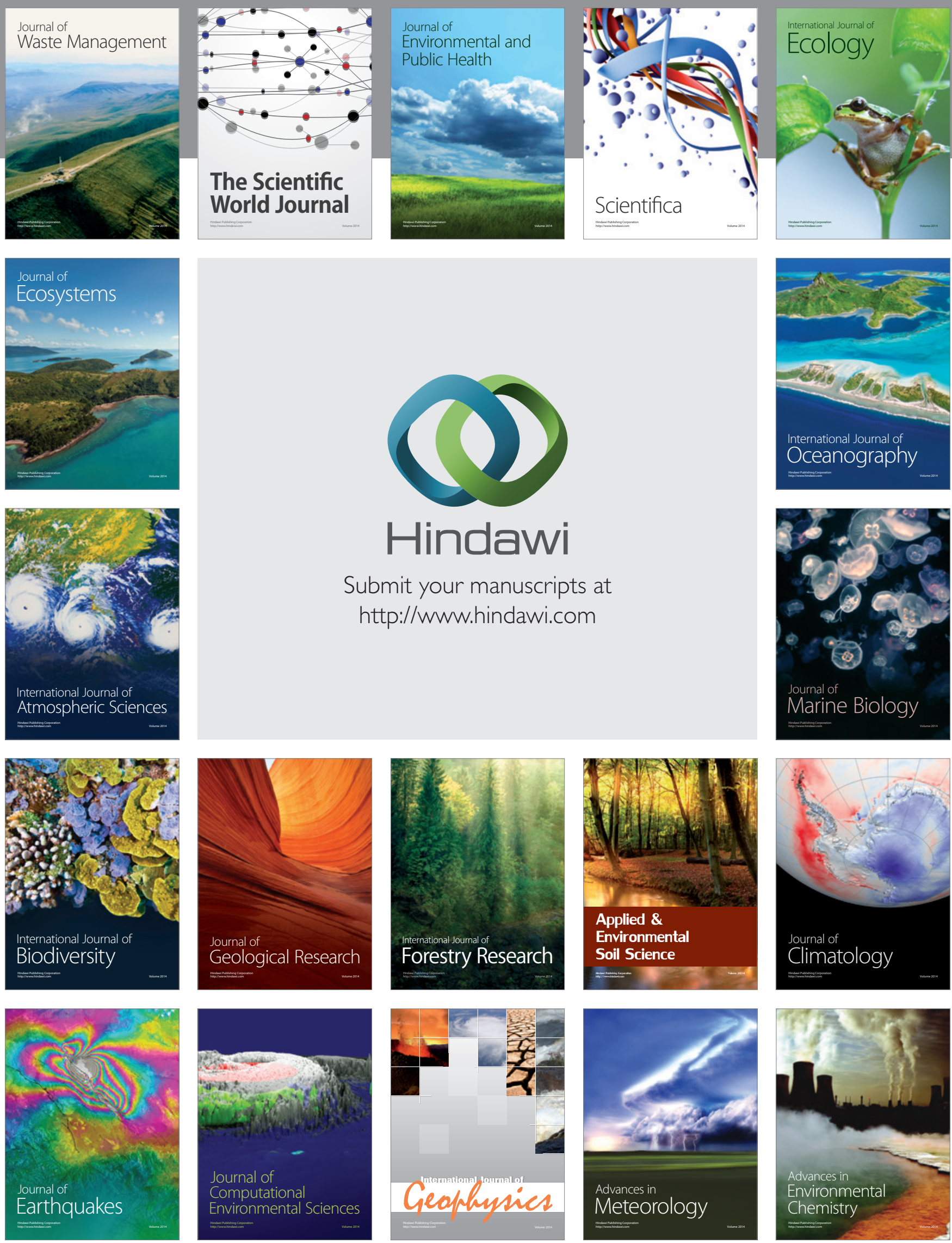